\title{
Kepemimpinan Desa dan Pengelolaan Sumber Daya Alam Aras Lokal di Tiga Desa Lereng Gunung Ungaran, Jawa Tengah
}

\section{Cahyo Seftyono ${ }^{1,2 *}$, Nugraheni Arumsari ${ }^{1,2}$, Erisandi Arditama ${ }^{1,2}$, Muhammad Luthfi1,3}

${ }_{1}^{1}$ Program Studi Ilmu Politik, Fakultas Ilmu Sosial Universitas Negeri Semarang, Gd. C4 Lt.1

Fakultas Ilmu Sosial, Universitas Negeri Semarang, Gn. Pati, Semarang 50229 Indonesia

2Pusat Kajian Politik Lokal-Universitas Negeri Semarang, Gd. C4 Lt.1 Fakultas Ilmu Sosial,

Universitas Negeri Semarang, Gn. Pati, Semarang 50229 Indonesia

3 Indonesian Institute for Development and Social Studies

Lamongan Barat VIII/18 Sampangan, Semarang 50232 Indonesia

Diterima : 3 Juli 2016; Disetujui : 25 September 2016; Dipublikasikan 14 Oktober 2016

\begin{abstract}
The interaction between the village leader or Lurah and citizens can be regarded as a fundamental process. Because, in this level leaders and the led will be interact intensively. This is in contrast to the higher levels of government, for example, at the district level, the city, even at the national level. At this lowest level, interaction and relations, social control, policies, support, and the rejection of the program will often occur. In the context of the wider innovation, village leaders are also required to develop social capital in managing human resource potential that exists. Therefore, the development of village- based management of village, hence, the development effort is the development that relies on strength, characteristics, and independent initiative of the village.
\end{abstract}

Keywords: leadership; village; local policy; natural resources management

\begin{abstract}
Abstrak
Interaksi antara kepala desa atau lurah dan warga di aras lokal dapat dikatakan sebagai proses yang fundamental. Sebab, pada level inilah pemimpin dan yang dipimpin akan bertemudan saling berinteraksi dan berrelasi secara intensif. Hal ini berbeda dengan level pemerintahan yang lebih tinggi, misalnya pada tingkat kecamatan, kabupaten/kota, bahkan pada level nasional. Pada level terendah inilah, interaksi dan relasi, kontrol sosial, kebijakan, dukungan, maupun penolakan program akan sering terjadi. Dalam konteks inovasi yang lebih luas, pemimpin-pemimpin desa juga dituntut untuk mengembangkan modal sosial dalam mengelola potensi sumber daya manusia yang ada. Sebab, pembangunan desa yang dilakukan berbasis pengelolaan sumber daya desa, maka, pembangunan yang diupayakan adalah pembangunan yang mengandalkan pada kekuatan, karakteristik, dan inisiatif mandiri desa.
\end{abstract}

Kata kunci : kepemimpinan; desa; kebijakan lokal; pengelolaan sumber daya alam

Cara Penulisan Sitasi : Seftyono, C., Arumsari, N., Arditama, E., Luthfi, M. (2016). Kepemimpinan Desa dan Pengelolaan Sumber Daya Alam Aras Lokal di Tiga Desa Lereng Gunung Ungaran, Jawa Tengah. Otoritas : Jurnal Ilmu Pemerintahan, 6(2), 60-70.

${ }^{*}$ Penulis Korespondensi.

E-Mail : cahyo.seftyono@mail.unnes.ac.id

Copyright (C) 2016, Otoritas : Jurnal Ilmu Pemerintahan, p-ISSN: 2088-3706, e-ISSN: 2502-9320 
Tersedia Online di http://journal.unismuh.ac.id/index.php/otoritas

Otoritas : Jurnal Ilmu Pemerintahan, 6 (2), Oktober 2016, 61

\section{Pendahuluan}

Kajian tentang pemerintahan desa di Indonesia saat ini merupakan isu yang kian menghangat. Terlebih dengan disahkannya UU Desa tahun 2014 lalu, maka posisi pemerintahan di aras lokal ini menjadi semakin dinamis. Sistem pemerintahan yang ada tidak hanya diselenggarakan melalui struktur administrasi yang bersifat top down sebagaimana relasi kelembagaan antara pemerintahan kelurahan dengan pemerintahan kecamatan, melainkan juga dinamika politik antara elit desa yang dipilih secara langsung oleh warganya dengan perangkat desa yang juga merefleksikan warga desa. Artinya, kontestasi politik tidak saja berkutat pada konflik kepentingan antar lembaga pemerintahan desa, melainkan juga terjadi di antara aktor-aktor yang ada di tingkat desa itu sendiri, baik aktor-aktor formal maupun informal.

UU Desa yang baru disahkan tersebut menjadi tonggak awal sebagai bagian dari visi pembangunan desa di Indonesia. Hal ini disebabkan pembangunan nasional akan bervisi pada desa atau pemerintah lokal. Bahkan lebih jauh, pemerintah melalui Kementerian Perencanaan Pembangunan Nasional/ Bappenas RI (Bappenas, 2015) telah menyatakan bahwa pembangunan akan dilakukan melalui pinggiran. Konsep pembangunan berbasis pinggiran dalam hal ini berarti visi pembangunan nasional akan difokuskan pada wilayah-wilayah yang tidak memiliki akses langsung terhadap sumber daya pembangunan. Dengan harapan, simpul utama pembangunan berbasis pinggiran ini akan mencapai titik kulminasinya pada tingkat perkotaan.

Saat kajian mengenai pemerintahan desa mengemuka, ada satu kajian lagi yang memiliki keterkaitan erat dengan kajian tentang pemerintahan desa. Isu kepemimpinan di tingkat desa menemukan momentumnya, sebagai kunci untuk memahami bagaimana penyelenggaraan dinamika pemerintahan desa. Isu kepemimpinan di tingkat desa juga penting untuk dikaji, sebab, pada tingkat inilah sebenarnya, sumber dayasumber daya yang ada terintegrasi secara langsung, termasuk sumber daya alam lokal. Dari titik ini dapat dikatakan bahwa, pengelolaan sumber daya alam secara langsung akan selalu beririsan dengan kepentingan masyarakat. Oleh karenanya, kepemimpinan dalam pengelolaan sumber daya alam menjadi keniscayaan dan penting untuk dikaji secara lebih mendalam. Kepemimpinan, dalam konteks ini, bukan hanya bermakna kemampuan memimpin, melainkan juga bagaimana kapasitas pemimpin di aras lokal berinteraksi dengan warga masyarakatnya.

Interaksi antara pemimpin (dalam hal ini lurah dan juga kepala desa) dan juga warga di aras lokal di tingkat desa dan kelurahan dapat dikatakan sebagai proses yang fundamental. Kepemimpinan merupakan salah satu indikator penting dalam pembangunan kapasitas komunitas serta ketahanan komunitas (Madsen dan O'Mullan, 2014). Sebab, pada level inilah pemimpin dan yang dipimpin akan bertemu dan saling berinteraksi dan berrelasi secara intensif. Hal ini berbeda dengan level pemerintahan yang lebih tinggi, misalnya pada tingkat kecamatan, kabupaten/kota, bahkan pada level nasional. Pada level terendah inilah, interaksi dan relasi, kontrol sosial, kebijakan, dukungan, maupun penolakan program akan sering terjadi. Sehingga, sinergitas antara kepentingan warga desa dengan kebijakan pemerintah desa dapat terwujud. Selain itu, sinergitas antara warga dan pemerintah desa juga penting untuk mengantisipasi menjadikan desa menjadi objek negaraisasi desa.

Oleh sebab itulah, pemerintah desa pun tidak dapat membuat dan menjalankan program seperti 
Tersedia Online di http://journal.unismuh.ac.id/index.php/otoritas

Otoritas : Jurnal Ilmu Pemerintahan, 6 (2), Oktober 2016, 62

kemauannya sendiri, berdasarkan kepentingan pribadi, maupun golongannya. Adanya batasan kekuasaan dan kewenangan yang dimiliki ini pada hakikatnya tidak semata karena adanya lembaga legislatif di tingkat desa, melainkan juga disebabkan oleh warga desa mengenal pemimpinnya dengan baik. Dengan mengenalnya, pemimpin selalu diawasi dan dipaksa untuk menjadi pribadi yang baik, sekaligus memiliki karakteristik yang pro-publik. Dengan demikian, transparansi kinerja pemerintah desa secara kelembagaan maupun komunikasi personal pemimpin desa menjadi syarat utama dalam mewujudkan sinergitas yang baik di antara warga dan pemerintah desa, serta aktor lokal yang lain.

Selain itu, melalui semangat inilah, kajian mengenai governance di desa juga menarik untuk terus dikaji, dikembangan, dan diwujudkan di dalam penyelenggaraan pemerintahan desa agar transparansi kinerja pemerintah desa dan sinergitas antar aktor senantiasa terwujud. Praksisnya, good governance di level desa mencakup otonomi desa yang meliputi pengambilan keputusan berbasis kearifan lokal di level desa. Sedangkan dari sisi ekonomi, merupakan pengelolaan sumber daya desa (baik sumber daya alam maupun sumber daya manusia) berbasis pada partisipasi, aspirasi, dan kepentingan dari warga desa itu sendiri (Dwipayana, 2003).

Pemimpin-pemimpin di aras lokal tingkat desa ini juga dituntut untuk membuat kebijakan yang mendukung performa, kemampuan, dan kepentingan warganya secara luas. Interaksi di antara mereka pun akan didorong dalam rangka memajukan potensi yang ada. Dorongan tersebut termasuk dalam upaya untuk memastikan, betapa pemimpin lokal harus mengetahui potensi wilayahnya sekaligus cara cerdas untuk memaksimalkan potensi tersebut. Hal ini tampak pada wilayah-wilayah yang memiliki sumber daya alam lokal yang dimanfaatkan sebagai salah satu sumber pendapatan asli desa (PADes).

Dalam konteks inovasi yang lebih luas, pemimpin-pemimpin desa juga dituntut untuk mengembangkan modal sosial, dikarenakan modal sosial adalah faktor penting dalam kaitannya dengan ekonomi dan pembangunan (Farr, 2004), serta sebagai bagian desain besar dari sebuah wacana yang berkembang, yang merupakan aspek non material, melingkupi aspek sosial, termasuk kebijakan publik, yang dibutuhkan dalam pembangunan ekonomi (Helliwell, 2005).

Penting pula untuk menjadi perhatian penting dengan keberadaan norma yang membentuk modal sosial. Bahwa norma terbentuk melalui tradisi, sejarah, tokoh kharismatik yang membangun sesuatu tata cara perilaku seseorang atau sesuatu kelompok masyarakat, didalamnya kemudian akan timbul modal sosial secara spontan dalam kerangka menentukan tata aturan yang dapat mengatur kepentingan pribadi dan kepentingan kelompok.

Segala tingkah laku modal sosial penduduk secara langsung digambarkan melalui norma, nilai dan aturan yang berlaku dalam masyarakat tersebut (Liu Dkk., 2014) Jaringan lembaga, sebagai bentuk jaringan kerjasama antar manusia, merupakan wujud konkrit dari modal sosial (Shideler dan Kraybill, 2009). Jaringan tersebut memfasilitasi terjadinya komunikasi dan interaksi, memungkinkan tumbuhnya kepercayaan dan memperkuat kerjasama, serta memperkuat mekanisme saling mengontrol.

Sebab, pembangunan desa yang dilakukan berbasis pengelolaan sumber daya desa maka, pembangunan yang diupayakan adalah pembangunan yang mengandalkan pada kekuatan, karakteristik, dan inisiatif mandiri desa tersebut (Maskun, 1994). Sehingga, pengelolaan yang ada tidak hanya mencakup potensi-potensi formal; seperti 
Tersedia Online di http://journal.unismuh.ac.id/index.php/otoritas

Otoritas : Jurnal Ilmu Pemerintahan, 6 (2), Oktober 2016, 63

pendidikan, ekonomis, dan sebagainya, melainkan juga meliputi rasa percaya (trust), jejaring sosial (network), hingga respon timbal balik yang lebih baik (resiprokal) di antara aktor lokal di dalamnya.

Kajian mengenai kepemimpinan dan pengelolaan desa di Indonesia sudah berjalan lama. Dapat dikatakan bahwa informasi terkait desa atau institusi setingkat desa di Indonesia sudah sama tuanya dengan keberadaan Indonesia itu sendiri (Antlov, 2002). Namun demikian, konsepsi tentang Desa mulai menguat ketika kepemimpinan Soeharto dalam rezim orde baru. Pada masa tersebut, terjadi keseragaman pemerintahan di tingkat desa, bahkan hingga mengatur desa-desa adat yang ada di banyak tempat di nusantara. Lebih jauh, diskursus politik elit desa juga mengalami pasang surut. Jika sebelumnya di tingkat desa terdapat lembaga-lembaga adat yang memiliki kekuasaan lebih tinggi dibanding desa secara administratif, maka pada masa orde baru hal ini menjadi ternegasikan (Juliantara, 2000). Otoritas administratif lebih berkuasa dalam menciptakan ideide pembangunan desa.

Perubahan tentang level desa mulai ada perubahan kembali ketika masa reformasi, dengan dikembalikannya kekhasan pemerintahan di level desa. Kekuasaan masyarakat lokal untuk mengelola desa mendapat legitimasi (Mubyarto, 2000; Widjaja, 2003). Di Sumatra Barat misalnya kita akan kembali menemukan adanya 'Nagari', di mana tetua adat memiliki pengaruh besar dalam pembangunan desa. Pengakuan desa-desa adat dalam pembangunan misalnya juga dapat kita temukan di beberapa wilayah di Bali, seperti Desa Panglipuran, Desa Tenganan yang saat ini juga menjadi objek wisata andalan berbasis desa.

Kajian yang akan dilakukan saat ini sedikit berbeda, mengingat pemberlakuan UU Desa no 6 tahun 2014 yang memberikan otonomi kepada desa secara lebih maksimal. Tidak hanya desa-desa adat, melainkan seluruh desa di Indonesia akan mendapat anggaran untuk menjalankan pembangunan. Oleh karenanya, kontestasi politik (baik dalam terminologi kekuasaan) maupun politik dalam wacana ekonomi menjadi sebuah kajian baru yang penting untuk dipetakan.

Lebih jauh, berkenaan dengan kepemimpinan dan peran komunitas dalam pembangunan di aras lokal berbasis sumber daya alam, peneliti mendapati bahwa kajian ini merupakan kajian yang multidisipliner. Pembangunan di tingkat lokal tidak dapat dikaji semata dari aspek politiknya saja, melainkan juga unsup kebudayaan dan juga ekonomisnya. Beberapa terbitan penulis terkait pembangunan berbasis sumber daya alam di aras lokal misalnya terkait pembangunan bantaran Kali CodeYogyakarta yang menemukan peran komunitas dalam mengisi pembangunan. Namun demikian ada pola kepemimpinan personal di tahap awal yang kemudian menjadi penggerak pembangunan. Di awal pembangunan kita kenal Rama Mangun Wijaya, maka dalam kurun 15 tahun terakhir kita dapati Totok Pratopo sebagai penggerak pembangunan bataran Kali Code (Seftyono, 2010). Sedangkan di tempat lain, peneliti juga menemukan pembangunan lokal berbasis sumber daya alam di wilayah Tasik Chini, PahangMalaysia di mana peran komunitas lokal dalam membuat jejaring nasional maupun internasional memiliki peran yang lebih signifikan dalam pembangunan (Seftyono, 2011). Beririsan dengan apa yang terjadi di bantaran Kali Code, pembangunan di sekeliling Tasik Chini juga melibatkan kampus sebagai jangkar dalam memperkuat relasi sosial politik untuk mengajukan gagasan-gagasan inovatif kepada pemerintah.

Mendaras beberapa penelitian sebelumnya, maka penelitian ini bertujuan untuk 
memetakan interaksi di antara elit politik desa dengan warga desa serta pola kebijakan antara pemerintahan lokal berbasis desa dan kelurahan di Tiga Desa Lereng Gunung Ungaran, Jawa Tengah.

\section{Metode Penelitian}

Metode yang digunakan Beberapa tahapan dalam penelitian ini terbagi menjadi dua skema besar: pencarian data sekunder maupun pengambilan data primer. Data primer sendiri merupakan bahan mentah yang nantinya akan dianalisis dengan menggunakan referensi-referensi sekunder yang didapatkan melalui jurnal maupun media baik online maupun cetak yang digunakan untuk pendalaman materi. Pencarian data primer, dilakukan melalui proses FGD (Focus Group Discussion) dan juga IDI (In Depth Interview) yang dilanjutkan dengan wawancara semi terstruktur maupun analisa verbatim. Setelah mendapatkan informasi primer dan sekunder, penelitian.

Namun demikian, untuk penulisan artikel ini, penulis baru mengembangkan kajian awal yang didasarkan pada wawancara menggunakan metode Purposive Sampling Method (Ritchie J. dkk., 2003). Pemilihan responden berdasarkan posisi strategis mereka. Responden yang di wawancara: (1) Curug Benowo-Kalisidi Kabupaten Semarang: Kepala Desa, Pengelola SDA, Tetua Warga. (2) GonoharjoNglimut Kabupaten Kendal: Sekeretaris Desa, Pengelola SDA, Sesepuh Warga, (3) Wisata Air Panas-Diwak Kabupaten Semarang: Kepala Desa, Pengelola Wisata Air Panas, Sesepuh warga.

\section{Hasil dan Pembahasan}

Kepemimpinan desa dan pengelolaan sumberdaya alam yang ada diaras lokal merupakan satu kesatuan yang tidak bisa terpisahkan. kepemimpinan desa secara langsung berimbas terhadap pengelolan sumberdaya alam yang ada di desa tersebut. Desa menjadi lembaga yang mandiri dituntun untuk bisa mengel- ola sumber daya (sumberdaya manusia dan sumberdaya alam) untuk mengembangkan desa dan tujuan akhirnya memberikan kesejahteraan kepada masyarakat desa.

Pengelolaan sumberdaya alam tidak bisa terlepas dari peran serta masyarakat dan pemerintah desa. Seperti yang terjadi di Desa Kalisidi - Kab. Semarang, Desa Gonoharjo - Kab. Kendal dan Desa Diwak - Kab. Semarang. Ketiga desa ini memiliki karakteristik alam yang hampir sama, ketiganya sama-sama berada di lerang gunung ungaran yang membuat ketiga desa ini memiliki sumberdaya alam yang kaya untuk bisa dikelola oleh masyarakat yang ada disekitarnya manjadi kawasan wisata.

Dari ketiga desa ini juga memiliki karakteristik sumberdaya alam yang hamper sama, Desa Kalisidi dengan curug/air terjunnya, Desa Gonoharjo dengan pemandian airpanas serta arung jeramnya, dan desa Diwak dengan pemandian air panas dan kebun buahnya. Melihat keunggulan ketiga desa yang sudah memiliki sumberdaya alam yang bisa menarik wisatawan untuk berkunjung sebagaimana yang tertera pada tabel 1 .

Awal mula munculnya objek wisata yang ada dikarenakan ada keinginan dari semua pikhak untuk bisa ikut merasakan manfaat yang ada dari alam yang bisa dirasakan secara langsung oleh masyarakat dengan coba mengelola sedikit demi sedikit sumberdaya alam menjadi objek wisata. Tahun 1992 Desa Gonoharjo ditetapkan oleh Pemerintah Kabupaten Kendal sebagai kawasan wisata, sehingga kondisi seperti ini mau tidak mau Desa Gonoharjo memang harus berbenah secara internal untuk bisa mewujudkan impian menjadi desa wisata.

Dorongan dari pemerintah kabupaten Kendal cukup besar dalam perwujudan desa gonoharjo sebagai desa wista, salah satau nya pembangunan infrastruktur fasilitas jalan sangat di utaman menuju kawasan wisata 
Tersedia Online di http://journal.unismuh.ac.id/index.php/otoritas

Otoritas : Jurnal Ilmu Pemerintahan, 6 (2), Oktober 2016, 65

Tabel 1. Pemetaan Potensi SDA dan Tantangan (Hasil Penelitian, 2016)

\begin{tabular}{|c|c|c|c|c|}
\hline No & Lokasi (Desa) & $\begin{array}{l}\text { Potensi } \\
\text { Wisata }\end{array}$ & $\begin{array}{l}\text { Mulai } \\
\text { Dijalankan }\end{array}$ & $\begin{array}{l}\text { Keunggulan dan } \\
\text { Pengelolaan }\end{array}$ \\
\hline 1 & $\begin{array}{l}\text { Kalisidi-Kab. } \\
\text { Semarang } \\
\text { (Curug } \\
\text { Benowo) }\end{array}$ & $\begin{array}{l}\text { Curug/ Air } \\
\text { Terjun }\end{array}$ & 2005 & $\begin{array}{l}\text { Pengelolaan sudah } \\
\text { modern, koordinasi } \\
\text { antara pemerintah } \\
\text { (Pem-kab dan } \\
\text { Perhutani) dan } \\
\text { warga juga berjalan } \\
\text { baik sehingga } \\
\text { terdapat pemasukan } \\
\text { yang relatif besar } \\
\text { bagi kas desa dari } \\
\text { pengelolaan SDA } \\
\text { yang ada. }\end{array}$ \\
\hline
\end{tabular}

\section{Penguatan \\ Kelembagaan dan Jejaring}

Pengelola berusaha
menunjukkan
komitmen untuk
mewujudkan
kebermanfaatan
kawasan wisata
kepada seluruh
masyarakt desa
kalisidi.

Keunggulan yang

dimiliki desa

Pendekatan kepada

nglimut adalah

sudah menjadi

kaswan destinasi

masyarakat dan

pihak swasta

dengan mengajak

wista yang cukup

lengkap dan

fasiliatas umumnya

pun sudah baik

sehingga hanya

perlu publikasi yang

masif dan

pengelolan wisata

yang bisa

memberikan

keuntungan secara

langsung kepada

desa. ikut serta aktif

dalam menjalankan potensi wista yang ada.

\begin{tabular}{llll}
\hline & Diwak-Kab. & Pemandian & \\
Semarang & Air Panas & \\
& & dan Kebun & \\
(Pemandian & Buah & 2016 \\
Air Panas & & \\
Diwak) & & \\
& & &
\end{tabular}

Pengelolaan SDA termasuk di dalamnya kebun buah merupakan kerja sama antara pemerintah desa dengan PT. Sido

Muncul

\author{
Manajemen konflik \\ dalam \\ pembangunan; \\ Kerja sama dengan \\ pabrik di sekeliling \\ Desa Diwak
}


gonoharjo ini, dan yang terbaru kondisi penerangan jalan pun sudah dipasang sehingga pengunjung yang ingin ke objek wisata yang ada di Desa Gonoharjo malam hari sudah ada penerangan jalan yang memadai.

Pembangunan yang dilakukan oleh Pemerintah Kabupeten Kendal menunjukkan ada nya keseriusan untuk mengelola kawasan wisata gonoharjo sehingga sampai saat ini terdapat beberpa kawasan wisata yang bisa diklasifikasin menjadi dua jenis yaitu pariwisata alam yang dikelola oleh pemerintah desa yang meliputi wisata arung jeram/refting, wisata kuliner, wisata pertanian, dan wisata kerajinan tangan. Sedangkan yang kedua pariwisata yang dikelola oleh pihak swasta yang meliputi perhotelan/ penginapan dan karaoke, wisata pemandian air pasanas alami (perhutani), pemandian air panas dan wista alam (Promas Greenlend) sebagaimana yang dijelaskan oleh Perangkat Desa Nglimut.

Pengelolan pariwisata yang dilakukan oleh desa tidak terlepas dari campurtangan masyarakatnya, seperti pengelolan arung jeram yang dilakukan kolompok masyarakat dusun ngelimut yang berkerja sama dengan karangtaruna untuk menjalankan wisata ini. Selain itu peran pemerintah desa dalam mengembangkan wisata arung jeram ini terlihat cukup besar, dikarenakan adanya suntikan dana dari pemerintah desa untuk membangun dan melengkapi peralatan penunjang kegiatan arung jeram, serta sering melibatkan pengelola untuk melakukan studi banding di tempat lain untuk bisa mengelola pariwisata ini dengan baik.

Secara keseluruhan pemasukan desa dari kegiatan pariwisata lebih banyak memperoleh dana bagi hasil yang diberikan oleh pemerintah kabupaten Kendal. Karena memang desa gonoharjo sudah ditetapkan menjadi desa pariwisata. Dana bagi hasil yang diberikan oleh dari pemerintah kabupaten sebesar 20\% dari dana yang disetorkan, sehingga kisaran dana yang diperoleh pemerintah desa gonoharjo sebersar Rp. 29 Juta-an yang dapat dikelola untuk kegiatan pembanguan pariwisata yang dikelola desa dan kegiatan pembangunan insfrastruktur desa sebagai penunjang pariwisata (Wawancara dengan Kepala Desa Nglimut).

Di sisi lain, Desa Gonoharjo, terlepas dari campur tangan pemerintah kabupaten, masyarakat desa kalisidi dengan pemerintah desa membuka kawasan wisata curuk pada tahun 2005. Awal mula pembukaan objek wisata curuk ini adalah curuk lawe selanjutnya di buat akses juga menuju Curuk benowo sampai saat ini kedua curuk pun sudah terdapat akses jalan yang menghubungkan keduanya sehingga lebih mudah dijangkau. Pengelolalan kawasan wisata curuk lawe dan curuk benowo tidak dapat terlepas dari kepemimpinan bapak Dimas Prayitno Putra selaku kepala desa dan Muhajirin selaku ketua LMDH (Wawancara dengan Kepala Desa Nglimut). Sebagai kepala desa yang tergolong muda, ia berhasil memperkenalkan obyek wisata Curug Lawe di kancah nasional melalui berbagai media massa. Kinerja kepala desa inilah yang secara perlahan menguatkan komunitas dan jejaring di luar desa.

Kebijakan yang di keluarkan oleh sesa lebih berfokus pada pengembangkan obyek wisata dapat mendorong peningkatan perekonomi masyarakat secara mikro. Dengan meningkatnya ekonomi masyarakat meningkat sehingga secara tidak langsung masyarakat ikut aktif mensukseskan program-program pemerintah desa sehingga da timbale balik didalamnya. Kepala Desa secara langsung memberikan kepercayaan kepada sebuah lembaga yang bernama lembaga masyarakat yang mengelola kawasan objek wisata seperti karangtaruna, PKK, Lembaga Masyarakat 
Tersedia Online di http://journal.unismuh.ac.id/index.php/otoritas

Otoritas : Jurnal Ilmu Pemerintahan, 6 (2), Oktober 2016, 67

Desa Hutan, dan kelompok-kelompok lain yang dibentuk desa untuk mengelola wisata. Dalam hal ini kepala desa sebagai pelindung dan sekaligus mengawasi berjalannya lembaga tersebut yang dikelola oleh kelompok-kelompok tersebut.

Di lain tempat, Kalisidi, pengelolaan Sumber Daya Alam juga berbasis komunitas yang dikoordinir oleh desa. Salah satu kelompok yang di bentuk oleh desa untuk mengelola kawasan wisata adalah Lembaga Masyarakat Desa Hutan yang disingkat LMDH. Lembaga ini merupakan lembaga yang dibentuk guna mengelola wisata di kawasan hutan yang dimiliki oleh Perhutani yang berada dikawasan pemerintah desa kalisidi yang secara langsung menglola kawasan wisata curuk lawe dan curuk benowo. Lembaga ini merupakan lembaga yang berjalan secara mandiri dan dikelola oleh masyarakat setempat. Dikatakan mandiri karena lembaga ini tidak menerima investasi dari pihak swasta dan pengelolaan sepenuhnya berada ditangan masyarakat, pendanaan pembangunnaya tidak pernah menggunakan anggaran dana desa sama sekali.

Sebagai upaya agar tidak terjadinya penyelewengan keuangan yang ada, kepala desa selalu melakukan monitoring dengan mengadakan evaluasi anggaran sebanyak dua kali dalam satu bulan. Bukan hanya ingin sukses di bidang pelayanan, tetapi sukses di bidang pengelolaan keuangan juga menjadi salah satu tujuan agar obyek wisata dapat berkembang lebih pesat. Sistem bagi hasil yang dilakukan oleh LMDH dengan Perhutani dan Desa menggunkan sitem bagi hasil persentasi pemasukan, adapun besaran yang diperoleh meliputi $25 \%$ di berikan kepada perhutani dan $75 \%$ dikelola oleh LMDH dan sebagai kas desa sebagaimana yang diutarakan oleh Perangkat Desa Kalisidi.

Salah satu faktor yang menyebabkan LMDH sukses mengembangkan wisata Curug
Lawe dan Benowo karena tidak adanya rangkap jabatan oleh setiap pengurusnya baik secara internal di pemerintah desa maupun di luar pemerintah desa. Sehingga setiap pengurus dapat lebih fokus dalam upaya meningkatkan pelayanan dan mengembangkan obyek wisata. Lembaga ini beranggotakan 12 orang yang berasal dari warga Desa Kalisidi. Selain keterlibatan secara langsung dalam pengelolan sumberdaya alam, masyarakat sekitar kawasan wisata juga terbantukan dalam roda perekonomian, meraka bisa membuka lapak-lapak untuk menjual makan maupun minuman sehingga bisa menambah pendapatan warga masyarakat.

Dari ketiga lokasi, yang paling muda dalam pengembangan sumber daya alam adalah Desa Diwak. Desa yang memiliki potensi air panas ini baru secara resmi disosialisasikan oleh pemerintah pada tahun 2016. Namun demikian, di saat yang sama, potensi yang dikembangkan tidak hanya terbatas pada pemandian air panas, melainkan juga kebun buah.

Kondisi tanah yang subur menyebabkan pemerintah memberikan bantuan benih dari pihak dinas pertanian dan dinas perkebunan, selain juga ada bantuan dari beberapa pihak swasta yang memberikan jaminan kerja sama beli panen bagi petani yang serius dalam mengembangkan pertanian dan perkebunan produksi di Desa Diwak.

Selain ditunjang oleh tiga desa yang memiliki potensi sumber daya alam yang sangat besar. Hadirnya kolaborasi antara Kepala Desa, Perangkat Desa, Masyakat dan Pihak Swasta dalam pembangunan juga memiliki andil yang sangat besar.

Peran aktif kelapa desa dalam pengelolan objek wisata khususnya yang ada di Desa Kalisidi bisa disebabkan karna usia kepala desa yang masih tergolong muda, dengan gaya kepemimpinan yang bisa merangkul semua pikhak dirasa menjadi rumus yang 
Tersedia Online di http://journal.unismuh.ac.id/index.php/otoritas

Otoritas : Jurnal Ilmu Pemerintahan, 6 (2), Oktober 2016, 68

sangat jitu untuk mengembangkan desa nya. Tanpa memandang basis masa pemilihan kepala desa desa kalisidi memposisikan sebagai seorang pemimpin yang bisa mengayomi masyarakatnya secara keseluruan sehingga tidak ada pembeda-bedan masyarakat yang dulu mendukung dalam Pilkades atau pun tidak, sehingga semua merasa sama sama memiliki.

Selain itu, karena memang masih termasuk golongan muda, kepala desa Kalisidi juga aktif dicmedia sosial, seperti Facebook, Twitter, Instagram, dan website. Teknologi informasi menjadi senjata dalam optimalisasi pengelolaan dan pembangunan SDA berbasis wisata (Xiang dkk., 2015). Semua keunggulan desanya dapat dinikmati di media-media tersebut, sehingga akses informasi lebih terbuka dan bahkan mudah diakses bagi khalayak umum. Artinya, kepala desa memahami betul potensi yang dimiliki kemudian menterjemahkan itu ke dalam program yang konkrit. Mendekatkan desa -masyarakat-dan pihak swasta dalam rangka menarik wisatawan.

Dalam pengembangan pengelolaan kawasan wisata alam perlu ada kepala desa yang aktif, kreatif, dan inovatif sehingga mampu memanfaatkan potensi Sumber Daya Alam yang dimiliki desa secara bijaksana. Dari ketiga kepala desa yang ditemui mereka semua mampu mengembangkan obyek wisata alam yang ada di daerahnya masing-masing menjadi destinasi wisata yang banyak dikenal dan diminati masyarakat, baik masyarakat sekitar Semarang dan Kendal maupun di luar kota.

Hal ini tidak dapat dipungkiri berkat gaya kepemimpinannya yang baik. Pengayoman dan kepercayaan yang diberikan kepada masyarakat baik secara perorangan maupun lembaga menjadikan desa sukses mengembangkan potensi sumber daya alam yang dimiliki desa.

Interaksi yang dilakukan antara kepala desa dan warga masyarakat menentukan kondisi pengelolaan sumberdaya alam yang ada di desa seperti yang terjadi di Desa Kalisidi, yang mana hal ini sedikti berbeda dengan apa yang terjadi di Gonoharjo dan Diwak. Kondisi yang terjadi di desa ini, kepala desa memberikan kepercayaan penuh kepada masyarakat untuk mengelola pariwisata sehingga masyarakat merasa terbantukan dengan sikap yang diambil oleh kepala desa. Interaksi kepala desa dengan masyarakat menciptakan simbiosis mutualisme. Hubungan ini merupakan satu hal penting agak program pembangunan bisa berjalan baik (Beer, 2014). Desa disini hanya sebagai lembaga yang mengontrol dan mengawasi jalannya pengelolaan pariwisata. Muncul kepercayaan dari kepala desa terhadap warganya yang mampu menjalankan visi pembangunan yang sudah disepakati bersama.

Dukungan masyarakat dalam mengelola kawasan wisata secara sukarela dan gotong royong membantu menjaga dan melestarikan lingkunganya agar tetap asri membuat kondisi desa semakin nyaman dan ramah terhadap pengunjung sehingga berefek pengunjung tidak bosan dan tidak jenuh untuk berwisata kembali.

Sehingga hubungan antara kepemimpinan kepala desa, masyarakat, dan pengelola kawasan wisata yang dimiliki desa memiliki korelasi yang sangat kuat, dengan adanya kepala desa yang mampu mengarahkan mengarahkan warga nya untuk ikut aktif dalam proses pembangunan desa membuat desa semakin berkembang. Sembari kemampuan mengendalikan potensi konflik kepentingan yang ada (Ratner dkk., 2013). Tidak terlepas dari itu daya dukung masyarakat dengan gotong royong membantu menyukseskan kegiatan pembangunan yang ada di desa juga tidak bisa dipandang dengan sebelah mata. 
Tersedia Online di http://journal.unismuh.ac.id/index.php/otoritas

Otoritas : Jurnal Ilmu Pemerintahan, 6 (2), Oktober 2016, 69

\section{Kesimpulan}

Kepemimpinan Desa dalam Pengelolaan Sumber Daya Alam merupakan instrument penting dalam pembangunan di aras lokal. Selain dikarenakan otoritas mereka yang memang besar akibat pemilihan langsung, posisi sebagai pemimpin di aras lokal menjadikan visi pembangunan desa sepenuhnya di tangan mereka. Termasuk dalam hal ini bagaimana kemudian mereka memaksimalkan potensi yang ada, sekaligus me-manage konflik yang mungkin muncul). Baik berkenaan dengan konflik ide-ide pembangunan berbasis prioritas, maupun konflik yang bersumber pada pendanaan yang terbatas. Oleh karenanya, kualitas personal maupun tim perangkat desa, serta penguatan modal sosial antara perangkat desa, masyarakat dan sektor usaha yang ada perlu ditingkatkan.

\section{Ucapan Terima Kasih}

Penelitian ini dikerjakan dengan dana Hibah Fakultas Ilmu Sosial Universitas Negeri Semarang tahun 2016. Asisten Penelitian yang membantu mengumpulkan data lapangan dan wawancara adalah Ustad Mangku Alam. Penulis bertanggung jawab penuh atas isi tulisan.

\section{Daftar Pustaka}

Antlov, Hans (2002), Negara dalam Desa, Patronase Kepemimpinan Lokal, Yogyakarta: Lappera Pustaka Utama.

Bappenas (2015), Membangun Indonesia dari Pinggir, Pelatihan Khusus Pendamping Sistem Info Desa dan Kawasan untuk 100 Kabupaten di Indonesia. Ciputat-tangerang Selatan, 16 Januari 2015.

Beer, Andrew (2014), Leadership and the Governance of Rural Communities, Journal of Rural Development, Vol. 34, pp. 254-262.

Dwipayana, AAGN Ari, (2003),
Membangun Good Governance di Desa, Yogyakarta: IRE Press.

Etuk, Lena E., Mallory L. Rahe, Mindy S. Crandall, Michaela Sektnan dan Sally Bowman, Rural Leadership Development: Pathways to Community Change, Community Development, Vol. 44 No. 4, pp. 411-425.

Farr, James (2004), Social Capital: A Conceptual History, Political Theory, Vol 32 No. 1, pp.6-33.

Helliwell, John F. (2005), Well-being, Social Capital and Public Policy, NBER Working Paper Series 11807.

Juliantara, Dadang (Ed.), (2000), Arus Bawah Demokrasi, Otonomi dan Pemberdayaan Desa, Yogyakarta: Lappera Pustaka Utama.

Liu, J., Qu, H., Huang, D., Chen, G., Yue, X.,Zhao, X., Liang, Z. (2014), The Role of Sosial Capital in Encouraging Residents Proenvironmental Behaviours in Community Based Ecotourism, Tourism Management, 41: 190201

Madsen, Wendy and Cathy O'Mullan (2014), 'Knowing me, knowing you': Exploring the Effects of a Rural Leadership Programe on Community Resilience, Rural Society, Vol. 23 No. 2, pp. 151-160.

Maskun, Sumitro H, (1994), Pembangunan Masyarakat Desa (Azas, Kebijaksanaan, dan Manajemen), Yogyakarta: Media Widya Mandala.

Mubyarto, dkk. (2000), Otonomi Masyarakat Desa, Perspektif Orang daerah dan Orang Desa di Enam Desa Jawa-Bali, Jakarta: Forum Pengembangan Partisipasi Masyarakat.

Ratner, B.D., Ruth Meinzen-Dick, Candace May, Eric Haglund (2013), Resource Conflict, Collective Action, and Resilience: An Analytical Framework, International Journal 
Tersedia Online di http://journal.unismuh.ac.id/index.php/otoritas

Otoritas : Jurnal Ilmu Pemerintahan, 6 (2), Oktober 2016, 70

of the Commons, Vo. 7 No.1, pp. 183-208.

Seftyono, Cahyo (2010), Local Community in Valuing Ecosystem Services: Warga Kampung Code's Perspective on Kali Code Existence, Proceeding 1st Annual Indonesian Scholars in Taiwan. doi: 10.2139/ ssrn.1763226.

Seftyono, Cahyo (2011), Pengetahuan Tradisional Ekologis Masyarakat Orang Asli Jakun dalam Menilai Ekosistem Servis di Tasik Chini, Malaysia, Jurnal Sosial PolitikUniversitas Gadjah Mada, Vol. 15 No. 1.

Shideler, David W. and David S. Kraybill (2009), Social Capital: An Analysis of Factors Infleuncing Investment,
The Journal of Socio-Economics, 38: 443-455

Widjaja, HAW. (2003), Otonomi Desa, Merupakan Otonomi Yang Asli, Bulat, Dan Utuh. Jakarta. Rajawali Press.

Xiang, Zheng, Vincent P. Magnini, Daniel R. Fesenmaier (2015), Information Technology and Consumer Behavior in Travel and Tourism: Insight from Travel Planning Using Internet, Journal of Retailing and Consumer Services, Vol. 22, pp. 244-249. 